\title{
Governing carbon mitigation and climate change within local councils: A Case Study of Adelaide, South Australia
}

\section{Commonwealth Journal of Local Governance}

Issue 10: December 2011- June 2012

http:/lepress.lib.uts.edu.au/ojs/index.php/cjlg

\section{Heather Zeppel}

Australian Centre for Sustainable Business and Development University of Southern Queensland, Springfield, Queensland

\begin{abstract}
There is growing concern about climate change impacts on local government areas. In Australia, the federal carbon tax (from 1 July 2012) will also increase costs for local councils. This paper evaluates what carbon mitigation (i.e. energy, water, and waste management) actions have been implemented by metropolitan Adelaide councils $(n=14)$ and why (or why not). A survey of environmental officers profiled carbon mitigation actions, emissions auditing, and motives for emissions reduction by Adelaide councils. The main reasons for adopting carbon actions were a climate change plan, climate leadership, and cost savings. Internal council governance of climate change actions was also evaluated. A climate governance framework based on adaptive management, communication, and reflective practice (Nursey-Bray 2010) was applied to assess climate mitigation by Adelaide councils.
\end{abstract}

Keywords: carbon mitigation, climate governance, local councils, Adelaide, South Australia

\section{Introduction}

Climate change impacts and carbon mitigation initiatives are key issues for local government (ALGA, 2009, 2010a, b). In this paper, 'Mitigation involves taking actions to reduce greenhouse gas emissions being emitted to minimise the impact from climate change' (QLGA, 2009, p. 58). In Australia, local governments that exceed an emissions threshold of $25,000 \mathrm{tCO}_{2}$-e, mainly from landfill emissions, are legally required to report their emissions under the National Greenhouse and Energy Reporting Act 2007. Local councils are also liable for fugitive emissions (over 25,000tCO $\mathrm{CO}_{2}$-e), from uncapped landfills and from stationary energy under the Clean Energy Act 2011 (Tax Ed, 2011). The associated carbon tax of $\$ 23 \mathrm{tCO}_{2}-\mathrm{e}$, set by the Australian federal government and effective from 1 July 2012, will also increase council costs for electricity, gas, fuel and materials. Local councils are thus implementing eco-efficiency measures in energy, water and waste management to reduce operating costs, meet state government targets, and address liability for carbon emissions. 
This paper reports on carbon mitigation actions adopted by the 14 Greater Adelaide councils in the wider metropolitan region of Adelaide and adjacent Adelaide Hills in South Australia. It begins by reviewing carbon programmes implemented by the Local Government Association of South Australia (LGASA), and then presents survey results profiling carbon mitigation actions, emissions auditing, climate governance, and motives for emissions reduction by Adelaide councils. This paper focuses on how local councils internally govern and implement climate change mitigation. It uses local government and local councils as equivalent terms.

Climate change and carbon mitigation are growing issues for Australian local government (Nursey-Bray, 2010; Pillora, 2011). Local government strategies and reports include advice and case studies on greenhouse gas mitigation for local councils (ICLEI, 2008; QLGA, 2009; ALGA, 2010a, b, 2011). During 1997 to 2009, some 238 Australian local councils participated in the 'ICLEI-Local Governments for Sustainability' ${ }^{19}$ Cities for Climate Protection (CCP) programme by recording emissions data and analysing the carbon footprint of council operations and local communities. New South Wales has surveyed local government needs in responding to climate change adaptation and mitigation (LGSA, 2006, 2010; Urbis, 2010). However, there is limited research on climate change mitigation actions by local government, apart from case studies of greenhouse gas reduction initiatives by CCP participants and other councils (Atkinson et al, 2007; ALGA, 2009; Hoff, 2010; ACELG, 2011; Pillora, 2011). In Queensland, one report has reviewed mitigation actions by selected south eastern local councils, prior to council amalgamations in 2008 (Burton, 2005, 2007), while a local government manual outlines climate mitigation actions for councils (LGAQ, 2009).

Research on carbon mitigation by local government includes climate change law and liability (England, 2008); methodologies to assess carbon emissions (Hamilton et al, 2008); climate change governance (Nursey-Bray, 2010); and an evaluation of carbon actions adopted by local councils in the CCP programme (Hoff, 2010). Hoff's (2010) review of carbon mitigation actions implemented by CCP councils in Australia and New Zealand found:

- $47 \%$ of councils had a climate change action plan; $36 \%$ had a cross-departmental plan,

- $94 \%$ of councils incorporated their climate change plan into a long term strategic plan,

- $76 \%$ of councils prioritised reductions of greenhouse gas emissions in action plans,

- 68\% of councils provided climate change education for schools and citizen groups,

- $63 \%$ of councils created positions such as a climate change officer/energy manager, and

- $21 \%$ of councils had a specific division responsible for climate change actions.

\footnotetext{
${ }^{19}$ ICLEI - Local Governments for Sustainability was founded in 1990 as the International Council for Local Environmental Initiatives
} 
Prior research examines carbon reduction initiatives adopted by one local council, reports on the outcomes of specific carbon programmes such as CCP (Hoff, 2010), or evaluates organisational responses to climate change by local government within one state (e.g. NSW in 2006, 2009 and 2010). There has been limited comparison of specific carbon mitigation actions adopted by a range of local councils or critical evaluation of climate change governance within councils. A study of Tasmanian council managers found key issues with climate change governance included uncertainty, communicating climate science to ratepayers, and developing institutional arrangements. A climate governance framework for local government thus needed to include three key dimensions: adaptive management, communications, and reflexive practice (NurseyBray, 2010). This paper evaluates climate governance within 14 local councils across the metropolitan area of Adelaide, the capital city of South Australia (SA).

This research focuses on climate change mitigation by local government (ACSBD, 2011). Its main aims are to:

- review and benchmark carbon mitigation measures implemented by local councils;

- evaluate motives for carbon emissions measures adopted by different local councils;

- identify key council staff and divisions responsible for climate change mitigation; and

- assess opportunities for local councils in sustainable technologies, renewable energy.

This paper explores the premise that similar to greening businesses, key motivations for ecological responsiveness by local councils are competitiveness, legitimacy, and social responsibility (Bansal and Roth, 2000). It also assesses the adoption of adaptive management, communication and reflective practice in climate change governance (Nursey-Bray, 2010) by Adelaide councils. The next section reviews carbon mitigation programmes by the Local Government Association of South Australia as a context for the survey of Adelaide councils.

\section{Local Government Association of South Australia}

The Local Government Association of South Australia (LGASA) has proactively led carbon mitigation measures for SA councils (Table 1). Key policy guidelines on mitigation actions by SA councils are outlined in the LGASA climate change strategy 2008-2012 (LGASA, 2008a), and the South Australian local government sector agreement - climate change (LGASA, 2008b). These LGASA mitigation programmes address the climate change and carbon reduction actions in South Australia's greenhouse strategy 2007-2020 (Government of SA, 2007); State government targets for climate action in South Australia's strategic plan 2011 updated from 2007 (Government of SA Plan, 2011), and A renewable energy plan for South Australia (Government of SA, 2011). 
The abatement goals for the State of South Australia include targets for emissions reduction, renewable energy, GreenPower, energy efficiency and zero waste (Table 1). The LGASA has set a target since 2007 for SA local councils to purchase at least 20\% GreenPower. Some 38 councils opted to procure 20\% GreenPower electricity in 2007 (LGASA, 2007). Carbon reduction goals are also included in: The 30-year plan for Greater Adelaide, and Adelaide Green City Sector Agreement (Government of SA, 2009, 2010). Seven Adelaide councils have climate change strategies (e.g. Adelaide City, Norwood, Payneham and St Peters, Onkaparinga, Port Adelaide Enfield, Salisbury, Tea Tree Gully, and Unley) with five included in this current study.

Table 1: Carbon mitigation programmes (LGASA) and greenhouse gas targets, South Australia

\section{Carbon mitigation programmes for councils by LGASA}

- $\quad$ climate change survey (2007)

- $\quad$ climate change summit, energy and carbon footprint audit survey (2008)

- $\quad$ renewable energy forum; update on NGERS reporting; (2009)

- $\quad$ Mutual Liability Scheme Climate Change Adaptation Programme (2009)

- $\quad$ briefing papers on carbon offsets for local government (2009/10)

- $\quad$ emissions measurement and management course, discussion paper on sustainable public lighting (2010)

- $\quad$ energy and climate change web survey, report about solar PV on council infrastructure (2010)

- $\quad$ Energymark trial report on household energy use (Mendham et al, 2010)

- Solar Councils Innovation Fund; Clean Energy Future update; carbon tax package update (2011)

- $\quad$ carbon tax modelling survey, climate change action plan guide (2011)

Greenhouse gas (GHG) reduction targets for State of SA

- GHG emissions reduction: limiting the state's GHG emissions to $108 \%$ of 1990 levels during 2008-12

- $\quad$ Renewable Energy: comprises 20\% of the state's electricity production and consumption by 2014, and 33\% by 2020

- $\quad$ GreenPower: buy renewable energy for 50\% of the government's electricity needs by 2014

- $\quad$ Energy Efficiency: improve efficiency of government buildings by $30 \%$ and dwellings by $15 \%$ by 2020

- $\quad$ Zero Waste: reduce waste to landfill by 35\% by 2020 (SA Plan, 2011)

Sources: Local Government Association of SA (www.lga.sa.gov.au); South Australia's strategic plan 2011 (SA Plan, 2011)

\section{Methodology}

South Australian local council websites were reviewed for information on climate change strategies, carbon mitigation and offsetting measures (Zeppel, 2011a). Other mitigation actions by local councils were identified from media articles, reports by CCP partners, and the climate change programmes of local government associations (e.g. ALGA, ICLEI, QLGA, and LGASA). Carbon mitigation actions in the Cities for Climate Protection programme were also assessed (Hoff, 2010). These provided the basis for the types of carbon mitigation actions listed in the council survey, along with questions about council motives for emissions reduction actions. The final survey included 28 questions in four sections: your local council; climate change; climate change mitigation; and carbon offsetting. The questions included a check list of climate change actions, open-ended questions on issues or reasons for climate responses, and rating of motives 
for carbon reduction actions by councils. A check list of 56 mitigation actions covered energy, water, waste, vehicles, and other council climate change initiatives. Two Sustainability Officers at Queensland local councils with climate change programmes provided feedback on a draft of this climate mitigation survey, with questions about constraints on climate actions by councils added. Information about LGASA carbon programmes and relevant SA government agencies (Zeppel, 2011a) was included in the survey.

The climate change mitigation survey of Greater Adelaide councils was conducted during June to October 2011. Councils were contacted using details on their corporate website. The target group for this survey was environmental or sustainability officers at SA councils. The survey was distributed by email and by post to 20 Greater Adelaide councils, with follow-up phone calls to confirm receipt and speak with environmental staff. An email was also sent to the network for sustainability officers at SA councils. A total of 14 councils (70\%) completed the carbon mitigation survey, by email or by post, with one survey completed via telephone interview. Three Adelaide councils declined to participate, as they lacked climate policies or staff covering this area, while three councils did not respond to emails or phone calls. The next section presents results from the survey of 14 Adelaide councils.

\section{Results}

The responding councils that completed the survey covered coastal, inner city and suburban councils, across the southern and northern regions of the Greater Adelaide region, into the Adelaide Hills. Of the responding councils, ten (71\%) had participated in Earth Hour 2011. The council staff completing the survey were: sustainability officers (57\%), including a sustainable energy coordinator; environmental officers (28\%); and sustainability planners (14\%). Hence, the survey respondents were predisposed to pro-environmental actions. Other council staff may have different opinions about climate change and carbon mitigation actions.

The 14 Adelaide councils covered both inner metropolitan and outer peri-urban/rural areas. The number of council staff ranged from 89 to 250 (7 councils); 300-395 (3 councils); 400-465 (3 councils), and one council with over 600 staff. The size of the regional population served by the council ranged from 20,000 to 52,000 people (8 councils), 80,000 to 133,000 people (5 councils), and one council with 160,000 people (10\% of state population). The main sources of cash revenue for these Adelaide councils was council rates (100\%); state or federal government grants (50\%); other council fees (43\%); and bank interest, or external contracting (14\%). The annual operating budget of the responding councils ranged from $\$ 15$ to $\$ 38$ million (5 councils), $\$ 62$ to $\$ 72$ million (4 councils), and $\$ 90$ to $\$ 106$ million (3 councils). In summary, the 14 Adelaide councils ranged from 89 to 600 staff, had operating budgets from \$15 million to \$106 million, 
and served populations ranging from 20,000 to 160,000 people. Council ability to implement climate change actions mainly correlated with their size and capacity (i.e. budget, staff), and the adoption of climate change strategy/policy.

All surveyed Adelaide councils reported damage from extreme weather events, mainly due to drought (71\%); heat waves (64\%); flash floods (57\%); bushfires (43\%); river floods and wind storms (36\%), and coastal erosion or storm surges (63\%). In regard to council insurance for damage to assets, eight respondents said yes ('but not sea related') while five were not sure or thought it could be in a mutual liability scheme. There was a focus on adaptation actions by councils, utilising federal government funding in the Local Adaptation Pathways Programme.

\subsection{Climate change and Greater Adelaide councils}

All of the surveyed Adelaide councils agreed that climate change was an important issue. Comments by ten councils on climate change impacts included damage to infrastructure (4), managing hazards (3), service delivery (3), council leadership on climate change (2), risk management (2), resilience (1), legal liability (1), and health and wellbeing (1). One coastal council mentioned sea level rise and the greater risk of flooding, with a climate change adaptation plan being prepared for western Adelaide. One environmental officer thought climate change was important 'however it is rarely on the radar of senior management or elected members who are more interested in roads, rates \& rubbish.' Another respondent noted the need for planning and holistic strategies by councils since 'climate change/variability has implications for roads, waterways, open space and buildings.'

The importance of climate change actions can be gauged by their coverage in council plans. Those council strategies or policies which included climate change were an: Environmental policy (64\%), Water management plan (50\%), or Waste management plan (50\%). Other specific climate change documents were: Climate change risk assessment (43\%); Climate change strategy (43\%) with one adopted in March 2011; Greenhouse gas or carbon neutral action plan (36\%); Climate change adaptation plan (28\%); Climate change policy (21\%); and Carbon emissions policy (21\%). Energy documents were: Sustainable energy action plan (21\%); Renewable energy policy (14\%); and Peak oil/energy transition plan or strategy (7\%). Other climate change strategies were included in environment plans (28\%), including a Healthy Environment Plan, Biodiversity Action Plan, and an Energy and Water Efficiency Management Plan that included 'energy, GHG and water objectives and targets.' 
The areas dealt with in council climate change plans included: Energy efficiency/conservation (93\%); Renewable energy (86\%); Waste reduction (71\%); Water conservation/water recycling (57\%); More sustainable living (residents) (57\%); Sustainable transport (57\%); and Sustainable business (industry) (21\%). One council included carbon actions for residents and businesses in their Community Wellbeing Plan, and Economic Development Plan, with another council reviewing climate change issues in their environmental plan for 2011/12. Other climate change areas addressed in six council plans were community engagement, public lighting, adaptation planning, and carbon reduction targets.

The council staff identified as primarily responsible for climate change issues included: Environmental or Sustainability Officers (78\%), and Environmental Managers (43\%). Others were: the Water and Waste Manager; Energy Manager; Sustainability Planner; and Infrastructure (one each, 7\%). One respondent noted climate change projects were assigned to relevant council units but the 'Sustainability Unit has responsibility for coordinating response.' Respondents identified the council sections responsible for climate change issues as: Planning and Environment/Sustainability (36\%); Environment team (21\%); Policy and Planning (21\%); Water and Waste (21\%); Infrastructure Services/Engineering (14\%); and Corporate Services (7\%). Two councils had a specific Sustainability Unit, or Sustainable Futures Department 'responsible for strategic planning and policy and coordination of Council's overall response to climate change; other departments are responsible for operational activities and initiatives (i.e. implementing the Plan)'. The climate initiatives that Adelaide councils participated in were: Cities for Climate Protection (CCP) (93\%); Earth Hour (78\%); Climate change workshop (57\%); Solar City or other solar scheme (43\%); Sustainable Street Lighting programme (43\%); National Water Initiative/Water Week (36\%); and NGERS report on emissions (28\%). Other climate change actions reported by four councils were: Emission reports (not NGERS); ZWSA Resource Efficiency Assistance Programme; and the LGASA Mutual Liability Scheme Climate Change Adaptation Programme.

The sectors targeted by councils for climate change actions were: Households (78\%); Community organisations (64\%); Businesses (57\%); Schools (50\%); Developers (28\%); Youth groups (21\%), and Landholders (14\%). One peri-urban council noted: 'we have tried to develop climate change activities with residents, but response rates are low', with 'limited active engagement external to the activities of Council (concentration on getting our own house in order).' Climate change initiatives were mainly funded by: Council operating budget (78\%); and State or Federal government grants (50\%). A few councils funded carbon actions with: council climate change action fund (14\%), one with a climate change response fund established in 2008; or cost savings generated by $\mathrm{CO}_{2}$ reductions (7\%) with a revolving climate action plan fund since 2005; and a 
council environmental levy or trust fund (7\%). The four councils with carbon action funds had also adopted climate change or energy strategies.

\subsection{Carbon mitigation by Greater Adelaide councils}

Respondents are strongly agreed $(71 \%)$ or agreed $(28 \%)$ that it was important to reduce the carbon emissions of their local council. Eight councils had employed a consultant to assess council emissions, with council staff internally assessing carbon emissions at six other councils. Three councils outsourced their emissions data collection and assessment to Planet Footprint, Balance Carbon and Energy Analytics. The main sources of carbon emissions reported by Adelaide councils, as a percentage of total council emissions, were:

- $\quad$ street lighting $(19-60 \%$, mean $=44 \%)$

- energy consumption (32-54\%, mean=37.5\%)

- $\quad$ water storage and pumping (24\%)

- council vehicle fleet (14-24\%, mean=17\%)

- other emissions (8.5\%)

Energy consumption included the electricity used for council lighting, office buildings and facilities, and, in one case, also for wastewater treatment plants, water storage and pumping. Other emissions, reported by one council, derived from fugitive sources, business travel, corporate waste, and paper consumption. In regard to street lighting, one respondent stated the Electricity Trust of SA (ETSA) charged councils more to install and service energy efficient bulbs in public lighting, while another noted: 'we have received advice that reporting requirements for street lighting will sit with ETSA.' One council commented on the accuracy of their emissions data, noting 'the last CCP inventory was for 2005/06 \& these data are out of date $\&$ there are questions about their accuracy.' The same council reported their vehicle fleet emissions in 2011 were about 16\%, down from 23\% in 2003.

The carbon calculators used to assess council emissions were: NGERS (36\%); council spreadsheet (28\%) using National Greenhouse Accounts factors; and ICLEI Greenhouse Gas Application (21\%). One council previously used CCP software to 'complete inventories of energy \& GHG emissions' but was 'now looking at an alternative that will align with NGERS reporting requirements even though we will not trigger mandatory reporting.' Key issues for councils in assessing carbon emissions were staff resources, reconciling accounts, formats, and data analysis. To manage accounts, one council had developed 'shared spreadsheets that are used to manage and track payment and energy/water use.' 
The Greater Adelaide councils adopted a wide range of emissions reduction actions (Table 2). The top 30 carbon mitigation actions mainly related to energy efficiency (56\%), fostering behavioural change (57\%), and water conservation (49\%) measures. The behaviour change actions related to providing information for residents, neighbouring councils, businesses and suppliers in reducing emissions, and internal council actions (targets, marketing, and staff). Other mitigation measures by councils were installing solar or heat pump hot water heaters, and roofing insulation, aquifer storage and recovery of reclaimed water (50\%), and capturing methane gas from landfills for power (36\%). Other carbon actions related to fuel efficient/LPG/hybrid electric vehicles (36-50\%), but few used biofuels (14\%). One council 'made smaller, energy efficient cars more financially viable in work packages but some staff still preferred larger car's, while 'waste services no longer had to use E10 in council vehicles (as) green waste bins cost extra to pick up.' Only one council in each case had installed a cogeneration or trigeneration power plant; used reverse osmosis to produce recycled water; or installed mini hydroelectric systems in water facilities. The carbon actions not implemented by Adelaide councils related to water and wastewater treatment as these services are mainly managed by SA Water. Overall, a total of 272 carbon actions were adopted by 14 Greater Adelaide councils (av. 19.4 measures out of 45 actions implemented). The number of carbon actions adopted by councils ranged from 8 to 29 mitigation measures.

Table 2: Top 30 emissions reduction initiatives by Greater Adelaide councils $(n=14)$

\begin{tabular}{lc} 
Energy Efficiency & $(\mathbf{n = 1 4 5}, \mathbf{5 6 \% )}$ \\
\hline Install solar photovoltaic (PV) power on council buildings & $(100 \%)$ \\
Purchase GreenPower electricity from renewable energy for council facilities & $(93 \%)$ \\
Install energy saving CFL bulbs or LED lights in council buildings & $(86 \%)$ \\
Install energy efficient computers in council offices/council libraries & $(78 \%)$ \\
Install energy \& water efficient technology in council amenities blocks\# & $(71 \%)$ \\
Solar powered public lighting (e.g. walkways) & $(71 \%)$ \\
Install timers, daylight sensors or motion detectors on council building lights & $(64 \%)$ \\
Purchase energy efficient appliances (e.g. fridges) & $(64 \%)$ \\
Install council-owned renewable energy generation systems & $(64 \%)$ \\
Install solar or heat pump hot water heaters in council buildings \& facilities & $(50 \%)$ \\
Install roofing insulation in council buildings \& facilities & $(50 \%)$ \\
Operate new fuel efficient council vehicles or vessels & $(50 \%)$ \\
Drive electric cars or hybrid-electric council vehicles & $(43 \%)$ \\
Use of dedicated LPG fuelled vehicles as part of council fleet & $(36 \%)$ \\
Capture methane gas from council landfills to generate power & $(36 \%)$ \\
Switch off council appliances at the wall to reduce standby power & $(28 \%)$ \\
Implemented any other energy initiatives & $(28 \%)$ \\
Install energy saving fluorescent or LED lights in street lighting & $(21 \%)$
\end{tabular}

\section{Behaviour Change}

Provide information to residents on reducing their emissions Include emissions reduction targets in council corporate plans 
Train staff or volunteers on your emissions reduction actions

Water Conservation

Practise rainwater harvesting (i.e. capture roof water from council buildings)

Practise stormwater harvesting \& filter through wetlands or bioretention system

Install energy \& water efficient technology in council amenities blocks\#

Produce or use recycled water - Class A+, Class A, Class B, Class C

Practise aquifer storage and recovery (ASR) of reclaimed water

\section{Waste}

Practise recycling and minimise amount of solid waste $(n=49,19 \%)$

(93\%)

Notes: \#Action 'Install energy \& water efficient technology in council amenities blocks' (10 responses) included in Energy Efficiency and Water Conservation actions. Total Top 30 Actions (n=259): Other carbon actions (1-2 responses): Energy efficiency (15), Water conservation (6)

The top five reasons for councils adopting emissions reduction actions (ranked 1 most important to 5 least important) were:

- council climate change strategy/action plan (1.8)

- demonstrate climate leadership to local businesses/residents (2.4)

- $\quad$ cost savings (2.5)

- differentiate your council as a 'climate friendly' region (3), and

- council resolutions on climate change/energy efficiency (3.2).

Other lower-ranked reasons included certification (e.g. CCP) (4.3), attracting low carbon industry investment (4.5), SA's Greenhouse Strategy or Act, and the LGASA climate change strategy (5). The main reasons for councils not adopting carbon actions were cost; staff resources; funding; asset ownership; measurement tools, and 'when payback periods are excessive (e.g. more than 15 years).' One council also noted, 'missed opportunities by staff/work areas not seeing this [climate change] as a priority'.

The main opportunities for Adelaide councils in reducing carbon emissions were identified as: waste management (50\%); green building design (50\%); renewable energy-solar, wind, cogeneration (50\%); sustainable technologies (43\%); water management (36\%); eco-efficiency measures (28\%); landfills (21\%); and carbon offset markets (14\%). Future carbon mitigation goals included recovery of waste for ethanol, aquifer recharge projects, and methane gas generation from landfills. One council aimed to 'maximise sustainable design and integration of appropriate technologies' at all developments.

Other comments about the role of local councils in carbon mitigation included:

\section{- 'Local Government is a leader in this space. More support from Commonwealth and}

State governments through partnerships are needed.' 
- 'Council should be focusing on avoiding or reducing their emissions as the offset side of things does not sit well with me.'

- 'Our Environmental Advisory Committee has decided to prioritise our funds into emission reduction and alternative energy generation for the current year.'

Survey results indicate the main focus of Adelaide councils is on reducing greenhouse gas emissions through a range of carbon mitigation and renewable energy measures. State and federal government support was also required to assist local councils in GHG reduction goals.

\section{Discussion: Implications for Climate Governance by Councils}

This study of emissions reduction actions by Greater Adelaide councils compares and highlights responses to climate change mitigation across one metropolitan region in South Australia. LGASA programmes and SA state government targets influence the carbon actions adopted by Greater Adelaide councils, with mitigation measures demonstrating leadership on climate issues to ratepayers and related agencies. Council responsibility for climate change issues was mainly delegated to environmental services, sustainability and planning areas, rather than infrastructure, finance or community development. Comments by environmental staff indicated they were committed to climate change actions, but sometimes lacked support from managers or other council areas.

Asset and finance managers have a strong role in council decision-making and need to be involved in implementing carbon reduction actions. The opinions of sustainability officers in regard to climate change issues may well differ from CEOS, other council managers or elected councillors (Nursey-Bray, 2011). Respondents from Adelaide councils noted the legal liability of councils for climate change actions, but some felt it was not a priority for funding or that staff missed opportunities to address climate change issues across council. Local government associations thus need to provide information on how climate change and carbon mitigation measures should be included in decision making by all sectors within local councils.

Nursey-Bray (2010, p. 173) also found Tasmanian councils were concerned about dealing 'with the uncertainty surrounding climate change impacts and how to incorporate climate change into day-to-day management or 'governance structures'. With the vagaries of ongoing climate change funding, Tasmanian council managers felt climate change management 'needed incorporating within governance regimes in more permanent and sustainable ways 'Nursey-Bray (2010, p 174). Respondents from Adelaide councils also wanted climate change incorporated within council operations. The research presented in this paper also found key elements of climate governance were adaptive management, communication and reflective practice (Nursey-Bray, 2010). 
Adelaide councils with climate change strategies and policies were integrating carbon mitigation across council operations, communicating proactive climate actions both internally (i.e. council staff) and externally (i.e. ratepayers), and reflecting on local carbon options. The City of Onkaparinga was a leader in this climate change area. The climate governance framework thus applies to carbon mitigation initiatives adopted by local councils such as energy efficiency, renewable energy, and other emissions reduction actions (Table 3). It includes carbon management actions and practices adopted within local councils and also climate governance networks with key stakeholders (i.e. residents, local groups, and experts). The actions listed for adaptive management, communication and reflexive practice thus provide a framework for assessing climate change actions by other local governments.

Table 3: Climate change governance framework for local councils (Nursey-Bray, 2010)

\section{Adaptive Management}

- Continually improving managerial practices for climate change (e.g. energy efficiency)

- Build on environmental assessment techniques and environmental management systems (GHG audit)

- Institutionalise climate change framework to implement varied policies, learning over time (e.g. plans)

- Mainstream climate change into existing council strategies and day-to-day business (climate proofing)

- Build more strategic alliances with ratepayers/local groups to trial mitigation and adaptation options

\section{Communication}

- Communicate climate change/variability using science; need to take proactive action; discuss options

- Communicate feasible climate change options for different groups (ratepayers, staff, councillors) and link/align climate change issue with local interests and agendas (e.g. solar PV power)

- Market climate change mitigation projects and schemes implemented by council

- Involve all interest groups (from community/conservation groups to the Mayor) in low carbon actions

- Add climate change into existing council processes for emergency management, health and safety etc and incorporate climate change guidelines into council policies (e.g. renewable energy)

\section{Reflexive Practice}

- Reflecting on global, national and state programmes for climate change mitigation by councils (e.g. CCP)

- Review other low carbon initiatives and practices and adapt these to suit local needs and locations

- Develop a council data base, web links, seminars on carbon mitigation products and services

- Work with other local councils on climate mitigation projects and initiatives to save time and money

- Build regional alliances and networks and allocate council funding to carbon mitigation actions

This paper found key motivations for ecological responsiveness by Adelaide local councils in reducing carbon emissions related to legitimacy and social responsibility in addressing State GHG targets, and competitiveness in terms of being a climate action leader (Bansal and Roth, 
2000; Zeppel and James-Overheu, 2012). Climate change actions were still mainly funded from council rates. Four Adelaide councils with carbon action funds had adopted climate change or energy strategies, while smaller councils lacked climate strategies or staff. Council ability to implement climate change actions mainly correlated with their size and capacity (i.e. budget, staff), and the adoption of climate change strategies/policies. Hoff (2010) found 45\% of CCP councils altered their council organisational structure to include positions or departments responsible for climate change actions. Only two Adelaide councils had specific sustainability units. Further support and funding is needed to assist local councils in developing climate change plans; auditing carbon emissions; and installing energy (e.g. cogeneration) or water efficiency measures. This will enable councils to meet their legal and community liability to reduce carbon emissions. Local councils in Australia are grappling with the financial implications of the federal carbon tax and its impact on council operations. Climate change governance by local councils in Australia will become more important with the implementation of the Clean Energy Act 2011 and the requirement for councils to audit and report their NGERS emissions over a threshold of $25,000 \mathrm{tCO}_{2}$-e.

\section{Conclusions}

This account of carbon mitigation actions by metropolitan local councils highlights climate governance issues and motives for reducing carbon emissions. The main reasons for Greater Adelaide councils to reduce greenhouse gas emissions were climate change plans; demonstrating climate leadership, cost savings, being a 'climate friendly' region, and carbon resolutions. Key motivations for local councils in reducing their carbon emissions are legitimacy (i.e. legislation, GHG targets), social responsibility (i.e. residents), and competitiveness (i.e. cost savings, leadership). A key challenge for many sustainability officers is communicating the need for carbon mitigation actions to all council divisions and managers, and to elected councillors. More research is needed on how local councils are addressing climate change governance and adopting carbon mitigation actions. This includes the key areas of council policies, funding, and staff resources for low carbon initiatives. Constraints to carbon mitigation actions by local councils also need to be reviewed. Crucial aspects of climate governance such as adaptive management, communication, and reflexive practice need to be further assessed within local government. This will highlight the impact of climate change practices on the organisational behaviour and governance of local councils, along with environmental, social, and business benefits from ‘climate proofing' councils. 


\section{Acknowledgements}

This paper was presented at the ACELG Local Government Researchers Forum, Local Governance in Transition, UTS Sydney, 14-15 December 2011. The research was funded with a Building Research Momentum Grant from University of Southern Queensland. The author thanks environmental officers at Adelaide councils that completed this survey. Any errors or omissions are inadvertent and are the sole responsibility of the author.

\section{References}

Atkinson, N., Brait, P., Murphy, L. and Rogers, N. (2007) Victorian local government greenhouse and climate change case studies report 2007, Municipal Association of Victoria, Melbourne, $<$ http://www.mav.asn.au/CA256C320013CB4B/Lookup/Victorian_Local_Government_Greenhouse _Case_Studies_Report_2007.pdf/\$file/Greenhouse\%20Report\%202007\%20final.pdf>, accessed on 8 November, 2011

ACSBD (2011) (Australian Centre for Sustainable Business and Development) 'Climate change mitigation by Queensland councils’, University of Southern Queensland, Springfield, <http://www.usq.edu.au/acsbd/projects/councils, accessed on 25 November, 2011>

ACELG (2011) (Australian Centre of Excellence for Local Government) 'Local government climate change Round table’, Sydney 4 May 2011, Research Papers, accessed on 8 November, 2011

<http://www.acelg.org.au/upload/programme1/1305089839_Climate_Change_Roundtable_Web.pdf>

ALGA (2009) (Australian Local Government Association) 'Debate on motions: Theme 1- climate change' In 2009 National General Assembly of Local Government Business Papers, ALGA, Deakin, ACT, $<$ http://www.alga.asn.au/, accessed on 8 November, $2011>$

ALGA (2010a) (Australian Local Government Association) Climate change: ALGA position paper and discussion document, ALGA, ACT, $2011<$ http://www.alga.asn.au/policy/, accessed on 8 November $>$

ALGA (2010b) (Australian Local Government Association) Climate change implementation plan20102014,,ALGA, ACT, <http://www.alga.asn.au> accessed on 8 November, 2011

ALGA (2011) (Australian Local Government Association) Towards a national planning framework for climate change mitigation and adaptation, ALGA, ACT, <http://www.alga.asn.au/, accessed on 8 November, 2011>

Bansal, P. and Roth, K. (2000) 'Why companies go green: A model of ecological responsiveness' Academy of Management Journal, 43(4), pp. 717-736.

Burton, D. (2005) 'South East Queensland's approach to climate change mitigation' Queensland Planner, 45(4), pp. 20-22.

Burton, D. (2007) Evaluating climate change mitigation strategies in South East Queensland. Research Paper 11, Urban Research Programme, Griffith University, Brisbane, accessed on 8 November, 2011<http://www.griffith.edu.au/_data/assets/pdf_file/0007/48580/urp-rp11-burton-2007.pdf>

England, P. (2008) Climate change law for planners, developers, local government and greenies: A quick stock take and some ideas for the future. Research Paper 16, Urban Research Programme, Griffith University, Brisbane, 2011 <http://www.griffith.edu.au/, accessed on 8 November >

Government of South Australia (2007) Tackling climate change: South Australia's greenhouse strategy 2007-2020, accessed on 8 November,2011

<http://www.climatechange.sa.gov.au/uploads/pdf/TACKLING_CLIMATE_CHANGE_STRATEGY.pdf

Government of South Australia (2009) The 30-year plan for Greater Adelaide, 2011 $<$ http://www.dplg.sa.gov.au/plan4adelaide/, accessed on 8 November >

Government of South Australia (2010) 'Adelaide Green City Sector Agreement', $<$ http://www.sa.gov.au/upload/franchise/Water,\%20energy\%20and\%20environment/climate_chang e/documents/sector_agreements/Adelaide_Green_City_sector_agreement.pdf, accessed on 8 November 2011> 
Government of South Australia (2011) A renewable energy plan for South Australia strategy paper, accessed on 8 November, 2011<http://www.renewablessa.sa.gov.au/files/111019-renewableenergy-plan-for-south-australia.pdf $>$

Hamilton, C., Kellett, J. and Yuan, X. (2008) 'Carbon profiling: An analysis of methods for establishing the local emissions baseline’, 3rd International Solar Cities Congress, RMIT, $<$ http://mams.rmit.edu.au/07ohncpzgy82.pdf, accessed on 2 May 2012>

Hoff, J. (2010) Local climate protection programme in Australia and New Zealand: Results, dilemmas and relevance for future actions. CIDEA project report no. 1, Department of Political Science, University of Copenhagen, Denmark, <http://egovernment.vuw.ac.nz/visiting\%20staff/Jens\%20Hoff\%20\%20Local\%20Climate\%20Jens_Hoff_Protection_Programmemes_in_Australia_and_New_Zealand _final.pdf, accessed on 8 November, 2011

ICLEI (2008) 'Carbon neutrality framework for local government', Prepared for the Australasian Mayors Council for Climate Protection by ICLEI Oceania, September 2008,

$<$ http://www.fremantle.wa.gov.au/files/223c5cc1-0c26-4b73-a4a69dac00ee6cad/A_ICLEI_Carbon_Neutrality_Framework_081031.pdf, accessed on 8 November, 2011

LGSA (2006) Responses to needs analysis survey to identify the climate change adaptation and mitigation needs for local government in New South Wales, November 2006, LGSA NSW, , 2011<http://www.lgsa-plus.net.au/resources/documents/2006_Needs_Analysis_Findings_Climate_Change_Adaptation__Mitigation.pdf, accessed on 8 November > LGASA (2007) 'GreenPower buy for 80\%', LGASA News, 97, p. 1.

LGASA (2008a) LGASA climate change strategy 2008-2012, LGASA, Adelaide, <http://www.lga.sa.gov.au/webdata/resources/files/Local_Government_Assoication_of_SA_Climat e_Change_Strategy_2008-2012.pdf, accessed on 8 November 2011>

LGASA (2008b) 'South Australian local government sector agreement - climate change', June 2008, $<$ http://www.lga.sa.gov.au/webdata/resources/files/South_Australian_Local_Government_Sector_A greement_-_ Climate_Change.pdf, accessed on 8 November, $2011>$

LGSA (2010) Local government needs in responding to climate change in New South Wales, Australia, LGA of NSW, Shires Association of NSW, NSW Government, NSW Environmental Trust, Sydney, <http://www.lgsaplus.net.au/resources/documents/Local_Government_Needs_in_Responding_to_Climate_Change_i n_NSW_December_2010.pdf, accessed on 8 November, 2010>

Mendham, E., Carr-Cornish, S. and Dowd, A.M. (2010) Final report South Australian Local Government Association Energymark trial, July 2010, CSIRO,

<http://www.lga.sa.gov.au/webdata/resources/files/LGASA_EnergyMark_Final_Report_reviewedSep2010 .pdf, accessed on 8 November, 2011>

Nursey-Bray, M. (2010) 'Local governance for local governments: A framework for addressing climate change’ Commonwealth Journal of Local Governance, 7, pp. 168-186.

Nursey-Bray, M. (2011) 'Learning and local government: The local government coastal management strategy South Australia,' 20 ${ }^{\text {th }}$ NSW Coastal Conference, Tweeds Head NSW, $<$ http://www.coastalconference.com/2011/papers2011/Melissa\%20NurseyBray\%20Full\%20Paper.pdf, accessed on 25 November, 2011>

Pillora, S. (2011) Australian local government and climate change. Working Paper No. 1, Australian Centre Excellence for Local Government, UTS, Sydney,<http://www.acelg.org.au/upload/ACELG_ClimateChangeReport_April11_v02_full.pdf, accessed on 25 November, $2011>$

QLGA (2009) Mitigating climate change: An introductory guide for Queensland local government, QLGA, Brisbane, <http://www.lgaq.asn.au/ , accessed on 8 November, $2011>$

SA Plan (2011) South Australia's strategic plan 2011, <http://saplan.org.au/media/BAhbBlsHOgZmSSIhMjAxMS8xMS8wNC8wMV8wMl8xNF8yMjNf ZmlsZQY6BkVU/01_02_14_223_file, accessed on 8 November, 2011>

Tax Ed (2011) 'The role of local government in Australia's clean energy future', 6 September, <http://www.taxed.com.au/news/display.html?Article_article_id=221, , accessed 8November 2011> 
Urbis (2010) Preparing for climate change in NSW: Local government responses to a global problem, March 2010, Urbis, <http://www.lgsa-, accessed on 25 November, 2011 plus.net.au/resources/documents/NSWCouncilsandClimateChangeUrbisSurveyMar2010.pdf>

Zeppel, H. (2011a) 'Climate change and South Australian local government: Action plans and resources', June 2011, USQ, Springfield, <http://www.usq.edu.au/acsbd/projects/councils>

Zeppel, H. and James-Overheu, C. (2012) 'Climate change mitigation by Greater Adelaide councils', International Journal of Organisational Behaviour, 17(2), pp. 29-34, accessed on 8 November, 2011. 